\title{
EMPLOYEE INNOVATION RESILIENCE: A PROPOSAL FOR MULTIDIMENSIONAL CONSTRUCT
}

\author{
Gonca ASLAN ${ }^{1}$ \\ Aylin ARAZA ${ }^{2}$
}

Başvuru Tarihi: 10.10.2015

Kabul Tarihi: 10.11.2015

\begin{abstract}
As being one of the prominent phenomenon in ecology, engineering and pyschology studies for more than thirty years, resilience has started to gain attraction and attention in management and organization fields in the last decade. The concept is accepted as an antidote of invulnerability (Weick, 1993), adaptive functioning against risk hazards (Rutter, 1987) and ability to cope with multiple changes (Boyd and Folke, 2012). Resilience is either defined as set of available and accessible behaviors over time that reflects growth (Ungar; 2010,2011) or as the maintenance of positive adjustment under challenging conditions (Vogus and Sutcliffe, 2007), it fosters the strenght and the survival of the organism. Resilience could be accepted in its infancy in management and organization studies, however, it has a great potential to understand how employees in organizations endure ongoing changes, challenges and uncertainty that reveal through innovation and its potential effects on innovation performance. Due to lack of any measurement scale in employee innovation resilience, in this study, we aim at proposing a model that presents innovation resilience as a second order multidimensional construct that consists of three dimensions and three sub-dimensions of each observable variables.
\end{abstract}

Keywords: Employee innovation resilience, emotional resilience, physical resilience, cognitive resilience, innovation performance

Jel Codes: M100, M120

\section{İ̧̧GÖREN İNOVASYON DAYANIKLILIĞI: ÇOK BOYUTLU YAPI İÇIN BİR ÖNERİ}

\begin{abstract}
$\ddot{O} Z$
Son otuz yıldır ekoloji, mühendislik ve psikoloji alanlarında öne çıkan kavramlardan biri olan dayanıklılık, yönetim ve organizasyon alanında da son on yıldır dikkat çekmeye başlamıştır. Kavram literatürde; kırllganliğın panzehiri (Weick, 1993), risklerden kaynaklanan tehlikelere uyumlanarak işleme (Rutter, 1987), ve çoklu değişikliklerle baş edebilme becerisi (Boyd ve Folke, 2012) olarak kabul edilmektedir. Dayanıklılık, ister zamanla büyümeyi etkileyen elverişli ve ulaşılabilir davranışlar setine, isterse zorlayıcı koşullara sürekli olumlu bir biçimde alışmaya işaret etsin, organizamanın gücünü ve yaşamsal şansını arttırmaktadır. Yönetim ve organizasyon çalışmalarında başlangıç aşamasında olduğu kabul edilse de kavram, işgörenlerin örgüt içinde devam eden ve inovasyon aracıllğ̆yla ortaya
\end{abstract}

\footnotetext{
${ }^{1}$ Arş. Gör., Yaşar Üniversitesi, İşletme Bölümü, gonca.aslan@yasar.edu.tr

²Dr., aylinaraza@gmail.com
} 
çıkan değişimlere, zorluklara ve belirsizliklere nasıl dayandıklarını ve söz konusu dayanıklılıklarının inovasyon performansları üzerindeki etkisinin ne olduğunu açıklama eğilimindedir. İsgören inovasyon dayanıklılığı ile ilgili bir ölçme aracı olmaması nedeniyle, bu çalışmada inovasyon dayanıklılı̆̆ı üç boyutlu ve her üç boyutununda üçer alt boyutttan oluşan üst düzeyli bir ölçme modeli olarak önerilmektedir.

Anahtar Kelimeler: Işsgören inovasyon dayanıklılığı, duygusal dayanıklılık, fiziksel dayanıklılık, bilişsel dayanıklılı, inovasyon performansı

Jel Kodlarl: M100, M120

\section{INTRODUCTION}

Recent developments in science, technology, and information technologies compel organizations to catch new realities of social and business life and expand their business horizons. Although innovation can be accepted as a driving force of economic, social, environmental and even cultural well-being of any society, it has drawbacks as well. For instance, organizations have to deal with adapting the "new" in their habitats, even if they are actors in a leading role (they are the innovators) or they are actors in supporting role (they are the followers). Probably the most difficult thing is to be resilient in highly sophisticated and complex environment. The necessity to synchronize human capital with innovation (both as a process and outcome), since innovation defined as the successful combination of hardware, software and orgware (Smits and Kulman, 2004), has become an important issue for organizations.

Jiménez-Jiménez and Sanz-Valle (2011:408) state whether innovation is conceptualized as process, outcome or both, the most of the definitions emphasize the adoption of a new idea or behavior. Thus, the new idea or behavior is to be accepted by the employees, and then diffuses whole organization and termed as "organizational policy". In order to be able to adapt new behavioral, cognitive and emotional patterns of any innovation, employees should have the strenght and capability to cope with change, accept it as a source of success and sustainability.

Organizational resilience has been discussed within the last two decades at largely macro level by ignoring the importance of micro analysis, and starting point of an organization; "A social unit of people that is structured around a specific skeleton in order to pursue collective goals". This so called "social unit of people" is proposed the key source of innovation resilience study due to the importance of understanding micro foundations of innovation resilience and firm success. Although, innovation has a great impact on regional development, it is a huge opportunity to enlarge your business and gain reputation and also this outcome 
(innovation) has deep impact on employees' work-life balance such as; job requirements, stress, capabilities, orientation, re-socialization and so forth. According to Wang et al. (2014:55), few organizations see resilience as a set of skills and attitudinal qualities that can be developed proactively and improve individual and organizational performance and well-being.

Although there have been different perspectives discussed the resilience concept in management and organization studies in micro level, all these écoles emphasize the strength of an organism that faces difficulties, yet developed coping skills with those difficulties and become stronger. Moenkemeyer et al.'s (2012:629-630) resilience taxonomy is a current and inclusive in management and organization field. According to the authors, there are three main domains examine resilience namely; a positive psychology perspective that accepts resilience one of the four key positive constructs of psychological capital (Youssef and Luthans, 2007) and consider resilience as a developmental concept of the positive individual and organizational outcomes. The second perspective addresses resilience as the employee openness towards change (Wanberg and Banas, 2000). The third area focuses on career resilience, "the ability of employees to bounce back after career setback" (Grzeda and Prince 1997:172, cited in Moenkemeyer, Hoegl and Weiss 2012:630).

The mentioned studies above focus on individual resilience in organizations, but none of them discuss resilience as a subject of innovation. Therefore, in this study, we develop the construct of employee innovation resilience as three dimensional second order construct; emotional innovation resilience, physical innovation resilience and cognitive innovation resilience.

\section{EMPLOYEE INNOVATION RESILIENCE: THE CONCEPT}

Resilience refers to a class of phenomena characterized by good outcomes in spile of serious threats to adaptation or development (Masten, 2001:228). Early researchs of resilience pointed out the importance of adaptibility and coping with stress (Wagnild and Young, 1993; Higgins 1994; Block and Kremen, 1996; Coutu, 2002). Ledesma (2014:2-3), in her study, categorizes resilience as the history of resilience studies and models of resilience. From history perspective, the author states that the resiliency theory has been discussed across many disciplines such as; psychology, psychiatry, developmental psychopathology, human development, change management, social sciences and so forth. Further she views three resilience models; compensatory model, the challenge model, and the protective factor of immunity versus vulnerability model respectively. Richardson (2002:308-309) in his metatheoretical study defines three waves of resiliency inquiry, namely; resilient qualities, the 
resiliency process and innate resilience. At the first wave resilient qualities of individuals (the character, trait or situational premises that individuals' hold), at the second wave the process of resiliency (how are the resilient qualities acquired) and at the third wave, motivational forces within the individuals that foster resiliency (there is a force within everyone that drives them to seek self-actualization, alturism, wisdom and harmony with a spirtual source of strenght) are being discussed.

Micro foundations of resilience in organizations mainly rest upon psychological side of the concept (Bonanno, 2004; Ungar, 2004; Luthans et al., 2006) and try to understand employees' individual dispositional resilience. However, some authors (Masten 2001; Masten and Reed, 2002, Sutcliffe and Vogus, 2003), view resilience as outcome of personality traits but also as a developable process. A new trend in organizations regarding resilience is to reveal the relationship between resilience and innovation. As far as it's known, there has been only two studies (Amir and Standen, 2011; Moenkemeyer et al., 2012) refocuse resilience in terms of innovation and performance expectancies. However, there has to be developed more concrete theory on resilience and innovation.

Maddi et al. (2005:8) describes how megatrends change everyday life of human being and employees as well. According to writers, due to ongoing expansion of internet and computer technology, the dramatic change in the nature of the job has occured. Thus, in order to keep up with this fast-moving job environment, employees should act quickly and keep learning unless they want to be obsolete. Therefore, employees are expected to be innovative, creative and adaptive to all unprecedented pace of environment. As organizations are still forms of humans and this labor force has to be effective, efficient and productive for the sake of organization's vitality from the beginning of capitalist discourse, it is important to understand how employees cope with pre-innovation and post-innovation periods. Employees are accepted to be capable of settling down in new innovation habitat. Hence, being able to reveal employee resilience to innovation is overlooked, yet urgent topic in management and organization studies in order to how decrease the negative outcomes of the innovation in terms of praxis. Therefore, in this study, the aim is to clarify the concept of employee innovation resilience by defining and discussing constituent components of the concept. As seen in Figure 1., we propose a research model that configures employee innovation resilience a second order three dimensional measurement model. 
Model 1. Employee Innovation Resilience Proposed Model

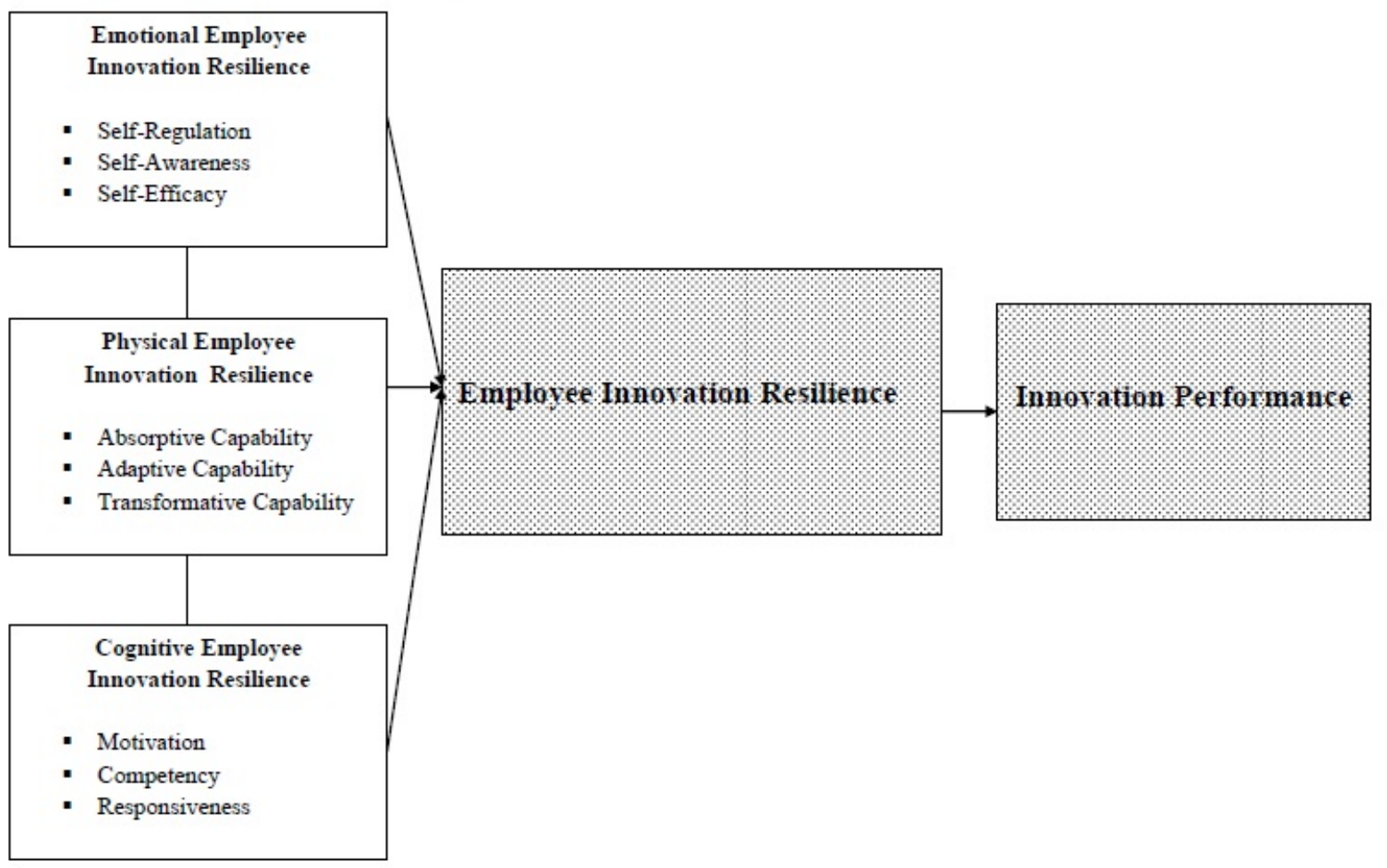

\subsection{Emotional Employee Innovation Resilience}

According to Masten and Obradovich (2007:14), "resilience is a broad conceptual umbrella, covering many concepts related to positive patterns of adaptation in the context of adversity". By Luthar et al. (2000:543), resilience is generally defined as "patterns of positive adjustment within the context of risk or adversity". Dealing with the same concept like it is a different phenomena leads researchers to attain a diversity in the definition of the concept in their studies. When it comes to the study of resilience emerging within the context of social sciences, the researchers need to narrow down the perspective reasonable enough to have linkages between concepts at ease. With that information in mind, researchers, who present appraisals of resilience, seem to use terms related to the concept like "emotional resilience" (Kline and Short, 1991:4) more eagerly in their work. In their research Feragen et al., (2010:278) stated that "emotional resilience may be a response, resulting from processes associated with friendships and positive social experiences". In this study, by maintaining emotional resilience, employees believed to be in need of merging their self-regulation, selfawareness and self-efficacy aspects for responding to innovations. Employees, being 
emotionally resilient to innovations is believed to help the organization maintain a rise in its performance.

Bandura (1991:248) stated that the concept of self-regulatory system lies at the very heart of processes and mediates the effects of most external influences but also provides the very basis for purposeful action. Adjusting to goal driven activities through situational constraints are allowed by self-regulation mechanisms. Studies that includes self-regulation clarify that the concept is consuming an energy which is depleted afterward. Individuals dominating responses are later less successful at controlling themselves (Morin, 2011:813-814).

The outcomes of self-regulation are a function of self-influence constituents, of external sources of influence and of goal-setting (Kuntz and Gomes, 2012:152). Self-regulation, which is an adaptive function of self-awareness, includes altering one's behavior, resisting temptation, changing one's mood, selecting a response from various options and filtering irrelevant information (Baumeister and Vohs, 2011:180-183). Bandura (1991:248) pointed out that selfregulation also encompasses the self-efficacy mechanism which plays a central role in the exercise of personal agency by its strong impact on thought, affect, motivation and action.

Self-awareness represents the "capacity of becoming the object of one's own attention" (Duval and Wicklund, 1972:9). In this state one actively identifies, processes and stores information about the self (Morin, 2011:807-808). Self-awareness, representing a complex multidimensional phenomenon, including various self-domains and corollaries, entails a sense of continuity as a person across time and also embodies a feeling of self as being distinct from the rest of the environment (Kircher and David, 2003:456). When self-awareness is heightened, the person is believed to be able to discriminate similarities and differences between the self's current state and the standard (Duval and Silvia, 2002:51). Self-awareness is beneficial (the why question) mostly because it makes self-regulation and inference about others' mental states possible (Morin, 2011:818). Self-awareness allows people to consider how they are perceived and evaluated by others (Leary and Terry, 2011:271).

Bandura (1977:193) defined the concept of self-efficacy as the "conviction that one can successfully execute the behavior required to produce certain outcomes" and assigned the concept as having a central role for analyzing changes achieved in fearful and avoidant behavior. He then redefined the concept as "a judgment of one's ability to execute a particular behavior pattern" (Bandura, 1978:240). It is seen that the concept of self-efficacy, unlike personality traits which are largely fixed, is state-like and dynamic and can change over time with new information, experience and learning. Therefore, it is believed to emerge as a major construct that may help explain and predict work related effectiveness (Luthans and Peterson, 
2002:379). For example, self-efficacy can be developed or changed through performance accomplishment, vicarious experience, social persuasion and the employee's physiological or emotional state (Dagher et al., 2015:241). As a result, self-efficacy is considered to be the belief that one can successfully show a set of behaviors in order to bring about a good outcome. (Fitzgerald and Schutte, 2010:495). Self-efficacy is another example of a set of personal skills and competencies (continuous learning, tolerance for ambiguity and uncertainty, autonomy, self-awareness etc.) which is in the content of the employees' psychological contract (Ballout, 2009:656).

Self efficacy beliefs also function as an important set of proximal determinants of human self-regulation and in addition to this, they affect the goal-setting subfunction of self-regulation (Bandura, 1991:257-258). Individuals with high self-efficacy beliefs is also believed to set higher career goals, put in more effort and pursue career strategies that lead to the achievement of those goals (Ballout, 2009:658). Being resilient is an outcome of these individual level selfinfluence emotional constituents' (self-regulation, self-awareness, self-efficacy) acknowledgement and management. When it comes to employees' external sources of influence of any kind like innovations, emotional resilience is agreed as an acceptable condition also. In addition to that, organizational performance attainment is counted on as an overall outcome of being innovation resilient.

\subsection{Physical Employee Innovation Resilience}

Wang and Ahmed (2007:35) define organization capacity as the deployment of resources, both explicit processes and tacit elements embedded in the processes. When it comes to employee capacity, it could be defined as the ability to deploy resources to go beyond the limits of an organism. Therefore, in order to become resilient to the changing environment as the outcome of an innovation, employees should go beyond the limits and oriented to the new ways and realities of doing things such as; divergent thinking, improvising, and so forth.

Physical innovation resilience is the capacity of an employee to act agile and reshape the physical conditions due to technical requirements of any innovative outcomes of an organization. Either innovation comes from the organism (employee) or inner circle (organization), the ability to absorb necessary technical knowledge and combine them with the existing one is one of the crucial dimensions of physical innovation resilience. Therefore, the employee's ability to meet the physical demands of specific innovation and its reflections as a post-innovation period is an important element of resilience. Being physically resilient to 
innovation could buffer the negative outcomes of becoming functionless in the organization, an increase the performance of both an employee and the organization. In order to be physically resilient, the employee should improve absorptive, adaptive and transformative capabilities.

In resilience studies, absorptive capacity defined as "the ability of the community to absorb event impacts using predetermined coping responses" (Cutter et al., 2008:663) or "the ability of a system to absorb change and disturbance without changing its basic structure and function or shifting into a qualitatively different state" (Holling, 19743:14). Whether it is the system, the community or the organization, coping is the key element of absorptive capacity. In order to cope with unknown or unpredictable, the ability to recognize the value of new information (Cohen and Levinthal, 1990:128), could be an important starting point to constitute communication networks and become physically resilient. Although, absorptive capacity relies upon prior knowledge, it also needs to obtain new knowledge and be able to link them and store for future use.

We proposed absorptive capability as one of the dimensions of physical innovation resilience, due to its effects on the organism's learning ability (Lane et al., 2006) and therefore its possible relationship with resilience. If learning describes the change in existing behavior of any organism, and yet absorptive capability is accepted as an ability to create new and applicable knowledge sets from both existing and potential knowledge, then absorptive capability could be assumed as a starting point of a physical change process. Developing and maintaining absorptive capacity is critical to a firm's long-term survival and success (Lane et al., 2006:833), for some reason the same situation is valid for the employee who faces an ongoing innovative process. Absorptive capacity proposes that prior related practices may inform the decision to adopt a new practice (Lenox and King: 2004:338).

When employees considered as cohesive organisms, the ability to form an interorganizational network and interpersonal network will be the source of physical resilience. However, forming a network as absorptive capability is not enough for an employee to become resilient to innovation. At the same time, an employee should be able to adapt new information that comes from the network. In biological perspective adaptation refers survival of an organism (Chakravarthy, 1982:35). It's about being able to become a part of changing conditions of a specific environment. Activities concerning adaptability is accepted to improve performance in the long term (Gibson and Brkinshaw, 2004:209-212), thus they help the organism to fit its environment. Adaptive capability is capacity to sense and respond to environmental changes (Ma et al., 2009:1087) or find better ways of doing things in response to its environment (Child, 
1997: 66-67). As Clegg indicates (1990:52), all open systems are meant to be inherently adaptive in order to evolve with changing environments.

Adaptation is a central part of resilience. Adaptation comprises knowledge in terms of anticipation (what to expect), attention (what to lookfor), and response (what to do) (Hollnagel and Woods, 2006, 350). Rather, it involves changes in strategic behavior (Schindehutte and Morris, 2001:85) that increases the viability and sustainability of the organism. In the face of innovation, employees either become inertial, resist changing conditions or act adaptively and move forward. In this study proposed as one of the dimensions of physical innovation resilience, adaptive capability is the ability of an employee to survive the conditions of post-innovation period and guarantee smooth transition from former to current realities of organizational innovation habitat.

Maguire and Cartwright (2008), arguing a similar point, explain that the transformation view of resilience is particularly useful for understanding how a community can respond positively to change. According to Walker et al. (2004:5), the capacity to create new system makes the existing system malfunction and introduce new components and ways of making a living by chancing the state variables defined as transformative capability. Accordingly, transformative capability is correspond to new state of an organism through change. In transformative capability, an employee is accepted to alter his/her behaviors due to the effects of post-innovation period on function, style, the structure of the company. Therefore, the capability to accept change and new ways of doing things within the firm will help employee to manage new demands of innovation. Transformative capability is the hardest stage of physical innovation resilience. Practice is the key element in transformative capability, the employee is accepted to practice new behavioral patterns continuously in order to execute the last step of physical resilience.

\subsection{Cognitive Employee Innovation Resilience}

Resilience is defined as "the ability of an individual to deal with difficulties and challenges in life" (Zamani et al., 2014:151). Intentions to overcome these changes can be originated from cognition. Therefore, cognitive resilience is considered as "an ability to identify and implement strategies that minimize the likelihood or consequences of cognitive mistakes" and is also described as "the creation and application of strategies for avoiding and mitigating error" (Furniss et al., 2012:96). In this study, resilience generates a link between employee cognition and innovation. 
Cognitive reactions in employees are believed to be effective in the innovation process. The organization's capitalizing on innovations can make employees to be innovation resilient according to their cognitive thinking. In understanding employee resilience to innovation, the goal is to determine the factors that effect employee behaviors, attitudes and perceptions when facing these innovations.

Organizational activities are considered to be the outcomes of employee actions. Since cognitive employee outcomes enrich the understanding of all organizational acts, it's relied on that the cognitive employee functions of motivation, competence and responsiveness may have an impact on influencing the innovation process (pre-innovation and post-innovation) and compensate the innovation based changes altogether for the organizations. It implies that employees' cognitively constructed work minds can make the organizations' workforce to be reasonably resilient when they act upon their motivation, competence and responsiveness against to innovation based changes. In other words, the challenge for employees is to deal with innovations is to be motivated, competent and responsive in order to be resilient cognitively. In short, in this study, we contend that employees' motivation, competency and responsiveness are believed to sustain resilience through innovations and therefore, the concept of employee innovation resilience (emotional, physical and cognitive) is claimed to be essential for the organizational innovation performance.

All activities of an organization are recognized by the performance of the organizaition's employees, which is based on their motivation level (Zámečník, 2014:851). The importance of employee motivation to perform well is related to the activities of the organization (Lau and Roopnarain, 2014:228-229). Motivation helps employees to achieve better performance for themselves as well as their organization. In other words, a motivated workforce means a better corporate performance (Nohria et al., 2008:7).

Vroom's (1964), "the expectancy theory of motivation" explains the process of individuals making decisions on various behavioral alternatives. The theory asserts the selection of the option with the greatest motivation force and in addition, the motivational force for a behavior, action or task is stated as a function of three distinct perceptions: expectancy, instrumentality, and valence (Chiang and Jang, 2008:313-314). As new motivational practices make employees to sustain competitiveness, boosting personal motivation is believed to bring satisfaction and success to the work. Therefore, an employee motivation is considered to be a crucial issue and an important asset for the organizations.

Motivation improvement depends on detecting and verifying expectations of the employees' current motivation conditions and the information gathered from this analysis helps 
to determine the strong and weak aspects of the motivation structure of the organization (Zámečník, 2014:852). Bandura (1977:193) states that self-motivation involves standards against which to evaluate performance. Motivationally oriented employees can be considered as resilient to organizational changes. Therefore, the motivational structure of the organization is trusted to be a creation of resilient employees for all kinds of organizational activities. Being integrated to innovations is an outcome of the organizations which have appropriate employee motivational systems.

The study extends the scope of employee innovation resilience and examines its direct effects on employee behaviours. Besides motivation behaviour, another important component of the related concept is observed to be competency. In general understanding for organizations, competencies are considered to be "the glue that binds existing businesses, also the engines for new business development" (Prahalad and Hamel, 1990:83). Organizational competence is the combination of human competence and physical resources respectively actions successfully carried out by individuals using operating resources and work equipment or material to contribute to the organizational performance (Schmiedinger et al. 2005:165). In other words, organizational competencies describe firm-specific resources and capabilities that enable the organization to develop, choose and implement value-enhancing strategies and include all firmspecific assets, knowledge, skills, and capabilities embedded in the organization's structure, technology, processes, and interpersonal (and intergroup) relationships (Lado and Wilson 1994:702). Core competencies on the other hand are the collective learning wich helps to to coordinate diverse production skills and integrate multiple streams of technologies in the organizations. According to Prahalad and Hamel (1990:81-82) they involve many levels of people and all functions.

The concept of the competency is linked with the individual perspective, experience, expertise, specialisation, intelligent expression, decision making and efficiency by most researchers and practitioners (Raudeliūnienè and Neimontas, 2012:58-59). From individual perspective, self competence is the overall sense of oneself as capable, effective and in control. It results from the successful manipulation of one's environment from the realization of goals, small and large. It is contingent upon the correspondence between individuals' strivings and the fairly objective results of their efforts to fulfill them (Tafarodi and Swann, 1995:325). Competence achieved by individuals viewed as resilient (Luthar et al., 2000:543). In this study 1t is claimed that human competence factor makes organizations' innovation process possible. Competency acts like a revolving door between being innovative and innovation resilient. Execution of innovation dosen't seem to be equal to assimilating the process. The change it 
causes and the responsibility it has makes it harder to outlast for the organization. Therefore, organization needs to be a unity of a innovation resilient employees who are competent enough for these innovations to happen continuously.

The importance of the concept of employee innovation resilience involves also the responsiveness trait of the employees. In times of increasing competition and constantly evolving customer needs, responsiveness to environmental changes has become a significant component for the orgnizations. Maintaining and enhancing an organization's responsiveness to customers and competitors has become an increasingly important managerial task in today's firms (Homburg et. al, 2007:18). A firm's organizational responsiveness and innovation strategy reflect its ability to act on the information it gathers from its market information system. In other words, organizational responsiveness is a firm-level strategic action. With increasing competition and constantly evolving customer needs, responsiveness to environmental changes has become a vital success factor for organizations (Wei and Wang, 2011:269-270).

Organizational responsiveness enables companies to quickly detect market changes, reconfigure their processes to meet new market requirements, share information across organizational borders, take maximum advantage of information processing systems and adopt new product and process technologies ahead of their competition. (Hoyt et al., 2007:1574). Responsiveness is an action taken in re-sponse to intelligence that is generated and disseminated. In summary, market orientation refers to the organization wide generation of market intelligence pertaining to current and future needs of customers, dissemination of intelligence within the organization and responsiveness to it (Kohli et. al, 1993:468).

Firms with high organizational responsiveness may utilize their various resources to meet the customers' needs or react to the competitors' decisions, while firms with a high innovation strategy may seek scarce resources to experiment with new ways to satisfy customers' needs and outperform their competitors in the long term. (Wei and Wang, 2011:267). Therefore, being responsive makes an organization to be more dependable in taking an action. As innovation is an everday activity not a future act of an organization, it needs to be adjusted by employees of the organization in order to be a daily tool not a long term goal. Responsiveness of the employees is seem to welcome the innovation act look a reasonable choice for the competitiveness of an organization by being resilient during the process.

\section{INNOVATION PERFORMANCE}


Innovation has the capacity to improve performance, solve problems, add value and create competitive advantage for organizations (Gloet and Terziovski, 2004:402). Innovation is mostly acknowledged as a driving force for competitive advantage or in other words, being important for the organizations in achieveing a superior business position. Facing the challenges of globalization, it is vital for an organization to manage to innovate effectively. Put it differently, an organization's level of globalization has significant consequences for its innovation performance. In addition to this, an increase in organization's employee resilience level, depending on the presence of value-added and value-created components of innovation, results in organization's innovation performance.

An organization offers a mindset or a plan regarding to the success of its innovation practices. For innovations to take place, organizations may leverage human capital to develop organizational expertise for creating new products and services. In their study Scott and Bruce (1994:603) pointed out that innovation becomes part of every employees' job description because of increasingly turbulent environments faced by the organizations. These deliberate practices entail individuals wanting to perform the tasks and making efforts to improve performance (Chen and Huang, 2009:104-105).

The authors Jong and Hartog (2010:27-34) stated that, the access to non redundant information and diverse social circles provided by weak ties are believed to facilitate several processes which are helpful for innovative work behaviour, including options for opportunity exploration, sources of ideas, and support to implement innovations. They also signified that understanding innovative work behaviour is important for the field of individual innovation and the employees, who have higher innovative work behaviours are believed to show more innovative output. For organizations to align strategy with innovative working are counted on developing a strategic plan which focuses on attainable innovation performance objectives (Patterson et al., 2009:50). In addition to this, Allegre et al. (2006:334) stated that "innovation performance is considered as an intermediate variable between certain processes and general firm performance, thus allowing a better picture of actions and effects within the firm to be obtained".

In order to achieve sustained innovation performance and to target interventions appropriately (and prioritise efforts accordingly), Patterson et al., (2009:36) clarified that organizations must access innovation metrics that are more accurate in measuring innovation across a wide range of work activities, including the contribution of employees. Similarly, Felin and Hesterly (2007:210) indicated that innovation performance was linked to knowledge and 
actions of the individuals and this knowledge individual-level initial conditions play an important confounding role in subsequent attributions of innovation performance. It is assumed that the behaviours of employees, for achieving innovation performance and maintaining the future innovation activities' development in the organizations, are determined by the individuals' resilience levels (emotional, physical and cognitive).

The stimulus factors of innovation determines the innovative capacity of organizations, which in turn determines innovation performance (in terms of product and process outcomes) (Prajogo andAhmed, 2006:504). Thus, the types of innovation (process, product, output, input etc.) and the scales (Gloet and Terziovski, 2004:406; Prajogo and Ahmed, 2006:515; Chen and Huang, 2009:113; Zeng et al., 2015:225) to gauge these types, show a measurement approach to the concept of overall innovation performance. Employees to engage in working towards the development of innovation performance depends on their individual resilience levels. Utilizing the employees' resilience based behaviours effectively, leads organizations to improve their innovation activities.

\section{CONCLUSION AND FUTURE RESEARCH}

The increased competition and fast-paced change in business environment forces organizations to be more innovative and expect their employees to be resilient in coping with the ongoing innovative activities. According to Neenan (2009:17), resilience comprises of cognitive, behavioral and emotional responses to adversities. Therefore, each of these components should accept as a resource to innovation processes within the firm. Employee behaviors have an important influence on organizational performance (Robertson et al., 1993:623). When innovation resilience viewed as a resource, it can be a valuable asset that contributes to employee outcomes such as job satisfaction and job performance (Bardoel et al., 2014:282). According to Youssef and Luthans (2007), being one of the components of employees' psychological resources, resilience tends to be positively related to high work performance. Hence, improved employee job performance is accepted to effect on both innovation performance and overall firm performance positively.

Ungar (2010, 2011) defines resilience as "a set of behaviors over time that reflect the interactions between individuals and their environments, in particular the opportunities for personal that are available and accessible". In a similar vein, innovation resilience could be defined as "the employee's cognitive, emotional and physical capacity to avert from the 
negative outcomes of innovation in the organization". New ideas, new policies, new methods could be damaging due to lack of resiliency of employees and can cause disturbance from an employee perspective.

The purpose of the present study is to clarify the concept of employees' innovation resilience through proposing second-order structure as, emotional (self-regulation, selfawareness, self-efficacy), physical (absorptive, adaptive and transformative capabilities) and cognitive (motivation, competency, responsiveness) resilience states. The further studies can operationalize proposed employee innovation resilience by constructing and testing second order structure of the concept.

\section{REFERENCES}

Alegre, J., Lapiedra, R., Chiva, R. (2006). A measurement scale for product innovation performance. European Journal of Innovation Management, 9(4), 333-346.

Amir, M. T., Standen, P. (2011). Employee resilience in organisations: Development of a new scale. Paper presented at the 26th Australian New Zealand Academy of Management Conference.

Ballout, H. I. (2009). Career commitment and career success: moderating role of self-efficacy. Career Development International, 14(7), 655-670.

Bandura, A. (1977). Self-efficacy: toward a unifying theory of behavioral change. Psychological review, 84(2), 191-215.

Bandura, A. (1978). Reflections on self-efficacy. Advances in behaviour research and therapy, 1(4), $237-269$.

Bandura, A. (1991). Social cognitive theory of self-regulation. Organizational behavior and human decision processes, 50(2), 248-287.

Bardoel, E. A., Pettit, T. M., De Cieri, H., McMillan, L. (2014). Employee resilience: an emerging challenge for HRM. Asia Pacific Journal of Human Resources, 52(3), 279-297.

Baumeister, R. F., Vohs, K. D. (2011). Self-regulation and the executive function of the self. In Mark R. Leary, June Price Tangney (eds.) $2^{\text {nd }}$ Edition, Handbook of self and identity, NewYork, Guilford Press, (pp.180-197).

Block, J.,Kremen, A. M. (1996). IQ and ego-resiliency: Conceptual and empirical connections and separateness. Journal of Personality and Social Psychology, 70(2), 349-361.

Bonanno, G. A. (2004). Loss, trauma, and human resilience. American Psychologist, 59, 20-28.

Boyd, E., C. Folke (2012). Adapting Institutions, Adaptive Governance and Complexity: An Introduction. In: Boyd, E. and C. Folke (eds.). Adapting Institutions: Governance, Complexity and Social-Ecological Resilience. Cambridge University Press, Cambridge, UK, pp. 1-8.

Chakravarthy, B. S. (1982). Adaptation: A promising metaphor for strategic management. Academy of Management Review, 7(1), 35-44.

Chen, C. J., and Huang, J. W. (2009). Strategic human resource practices and innovation performance-The mediating role of knowledge management capacity. Journal of Business Research, 62(1), 104-114.

Chiang, C. F., and Jang, S. S. (2008). An expectancy theory model for hotel employee motivation. International Journal of Hospitality Management, 27(2), 313-322. 
Child, J. (1997). Strategic Choice in the Analysis of Action, Structure, Organizations and Environment: Retrospect and Prospect. Organization Studies, 18(1), 43-76.

Clegg, S. (1990). Modern Organizations: Organization studies in the Postmodern World. Sage Publications Ltd., UK.

Cohen, W. M., Levinthal, D. A., (1990). Absorptive capacity: a new perspective on learning and innovation. Administrative Science Quarterly, 35(1), 128-152.

Coutu, D. L. (2002). How resilience works. Harvard Business Review, 80(5), 46-55.

Cutter, S. Barnes, L. Berry, M., Burton, C., Evans, E., Tate, E., Webb, J. (2008). A Placebased Model for Understanding Community Resilience to Natural Disasters. Global Environmental Change, 18(4), 598-606.

Dagher, G., Chapa, O. and Junaid, N. (2015). The historical evolution of employee engagement and self-efficacy constructs: an empirical examination in a non-western country. Journal of Management History, 21(2), 232-256.

De Jong, J., Den Hartog, D. (2010). Measuring innovative work behaviour. Creativity and Innovation Management, 19(1), 23-36.

Duval, S., and Wicklund, R. A. (1972). A theory of objective self awareness. The University of Michigan, Academic Press.

Duval, T. S., and Silvia, P. J. (2002). Self-awareness, probability of improvement, and the self-serving bias. Journal of personality and social psychology, 82(1), 49-61.

Felin, T., and Hesterly, W. S. (2007). The knowledge-based view, nested heterogeneity, and new value creation: Philosophical considerations on the locus of knowledge. Academy of Management Review, 32(1), 195-218.

Feragen, K. B., Kvalem, I. L., Rumsey, N., and Borge, A. I. (2010). Adolescents with and without a facial difference: the role of friendships and social acceptance in perceptions of appearance and emotional resilience. Body Image, 7(4), 271-279.

Fitzgerald, S. and Schutte, N. S. (2010). Increasing transformational leadership through enhancing self-efficacy. Journal of Management Development, 29(5), 495-505.

Furniss, D., Back, J. and Blandford, A. (2012, August). Cognitive Resilience: Can we use Twitter to make strategies more tangible?. In Proceedings of the 30th European Conference on Cognitive Ergonomics (pp. 96-99). ACM.

Gibson, C. B. and Brikinshaw, J. (2004). The antecedents, consequences, and mediating role of organizational ambidexterity. Academy of Management Journal, 47(2), 209-226.

Gloet, M. and Terziovski, M. (2004). Exploring the relationship between knowledge management practices and innovation performance. Journal of Manufacturing Technology Management, 15(5), 402-409.

Higgins, G. O. (1994). Resilient adults: Overcoming a cruel past. San Francisco, CA: Jossey-Bass.

Hollnagel, E. and Woods, D.D. (2006). Epilogue: Resilience Engineering Precepts. In: E. Hollnagel, D.D. Woods, N. Leveson (Eds.), Resilience Engineering - Concepts and Precepts. (pp. 347-358), Ashgate Publishing Company.

Holling, C. S. (1973). Resilience and Stability of Ecological Systems, Annual Review of Ecology and Systematics, $4,1-23$.

Homburg, C., Grozdanovic, M. and Klarmann, M. (2007). Responsiveness to customers and competitors: the role of affective and cognitive organizational systems. Journal of Marketing, 71(3), 18-38.

Hoyt, J., Huq, F. and Kreiser, P. (2007). Measuring organizational responsiveness: the development of a validated survey instrument. Management Decision, 45(10), 1573-1594. 
Kircher, T. and David, A. S. (2003). Self consciousness: An integrative approach from philosophy, psychopathology and the neurosciences. In T. Kircher and A. S. David (Eds.), The Self in Neuroscience and Psychiatry (pp. 445-474). Cambridge, UK: Cambridge University Press.

Kline, B. E. and Short, E. B. (1991). Changes in emotional resilience: Gifted adolescent females. Roeper Review, 13(3), 118-121.

Kohli, A. K., Jaworski, B. J. and Kumar, A. (1993). MARKOR: a measure of market orientation. Journal of Marketing research, 30(4) 467-477.

Kuntz, J. R. and Gomes, J. F. (2012). Transformational change in organisations: a self-regulation approach. Journal of Organizational Change Management, 25(1), 143-162.

Lado, A. A. and Wilson, M. C. (1994). Human resource systems and sustained competitive advantage: A competency-based perspective. Academy of management review, 19(4), 699-727.

Lane, P. J., Koka, B. R. and Pathak, S. (2006). The reification of absorptive capacity: A critical review and rejuvenation of the construct. Academy of Management Review, 31(4), 833-863.

Lau, C. M. and Roopnarain, K. (2014). The effects of nonfinancial and financial measures on employee motivation to participate in target setting. The British Accounting Review, 46(3), 228-247.

Ledesma, J. (2014). Conceptual Frameworks and Research Models on Resilience in Leadership. Sage Open, JulySeptember, 1-8.

Lenox, M. and King, A. (2004). Prospects for developing absorptive capacity through internal information provision. Strategic Management Journal, 25(4), 331-345.

Luthans, F. and Peterson, S. J. (2002). Employee engagement and manager self-efficacy. Journal of Management Development, 21(5), 376-387.

Luthans, F., Vogelgesang, G. R., and Lester, P. B. (2006). Developing the psychological capital of resiliency. Human Resources Development Review, 5(1), 25-44.

Luthar, S. S., Cicchetti, D. and Becker, B. (2000). The construct of resilience: A critical evaluation and guidelines for future work. Child Development, 71, 543-562.

Ma, X., Yao, X., Xi, Y. (2009). How do interorganizational and interpersonal networks affect a firm's strategic adaptive capability in a transition economy?. Journal of Business Research, 62(11), 1087-1095.

Maddi, S. R., Khosabha, D. M. (2005). Resilience at work: How to succeed no matter what life throws at you. New York: AMACOM.

Maguire, B. and Cartwright, S. (2008). Assessing a community's capacity to manage change: A resilience approach to social assessment. Canberra: Bureau of Rural Sciences.

Masten, A. S. (2001). Ordinary magic: Resilience process and development. American Psychologist, 56(2), 227239.

Masten, A. S., Reed, M. G. J. (2002). Resiliency in development. In C. R. Snyder \& S. J. Lopez (Eds.), Handbook of positive psychology. New York: Oxford University Press.

Masten, A. S. and Obradović, J. (2006). Competence and resilience in development. Annals of the New York Academy of Sciences, 1094(1), 13-27.

Moenkemeyer, G., Hoegl, M., Weiss, M. (2012). Innovator resilience potential: A process perspective of individual resilience as influenced by innovation project termination. Human Relations, 65, 627-655. 
Morin, A. (2011). Self-awareness part 1: Definition, measures, effects, functions, and antecedents. Social and Personality Psychology Compass, 5(10), 807-823.

Neeanen, M. (2009). Developing Resilience: A Cognitive-Behavioural Approach. Routledge: London.

Nohria, N., Groysberg, B., and Lee, L. (2008). Employee motivation: A powerful new model. Harvard Business Review, 86(7/8), 78-83.

Patterson, F., Kerrin, M., Gatto-Roissard, G., Coan, P. (2009). Everyday innovation: how to enhance innovative working in employees and organisations.

Prahalad, C. K and Hamel, G. (1990). The core competence of the corporation. Harvard BusinessRreview, 68(3), 79-91.

Prajogo, D. I., and Ahmed, P. K. (2006). Relationships between innovation stimulus, innovation capacity, and innovation performance. RandD Management, 36(5), 499-515.

Raudeliūnienė, J., and Neimontas, M. (2012). Employee competency integrated assessment: the example of the public relations specialists of the Lithuanian armed forces. Contemporary Issues in Business, Management and Education, 15 November, 2012, Vilnius, Lithuania, 57-68.

Richardson, G. E. (2002). The meta-theory of resilience and resiliency. Journal of Clinical Psychology, 58, 307321.

Robertson, P. J., Roberts, D. R., Porras, J. I. (1993). Dynamics of planned organizational change: Assessing empirical support for a theoretical model. Academy of Management Journal, 36(3), 619-634.

Rutter, M. D. (1987). Psychosocial Resilience And Protective Mechanisms. American Journal of Orthopsychiatry, 57(3), 316-331.

Schindehutte, M. and Morris, M. H. (2001). Understanding strategic adaptation in small firms. International Journal of Entrepreneurial Behaviour and Research, 7(3), 84-107.

Schmiedinger, B., Valentin, K. and Stephan, E. (2005). Competence based business development-organizational competencies as basis for successful companies. Journal of Universal Knowledge Management, 1, 13-20.

Scott, S. G., Bruce, R. A. (1994). Determinants of innovative behavior: A path model of individual innovation in the workplace. Academy of management journal, 37(3), 580-607.

Smits, R, S Kuhlmann. (2004). The rise of systemic instruments in innovation policy. The International Journal of Foresight and Innovation Policy, (1/2), 4-32.

Sutcliffe, K., Vogus, T (2003). Organizing for resilience. In: Cameron KS, Dutton JE and Quinn REQ (eds) Positive Organizational Scholarship: Foundations of a New Discipline. San Francisco, CA: Berrett-Koehler, 94110.

Tafarodi, R. W. and Swann Jr, W. B. (1995). Self-linking and self-competence as dimensions of global self-esteem: initial validation of a measure. Journal of Personality Assessment, 65(2), 322-342.

Leary, M. R. and Terry, M. L. (2011). Hypo-Egoic Mindsets: Antecedents and Implications of Quieting the Self, In Mark R. Leary, June Price Tangney (eds.) $2^{\text {nd }}$ Edition, Handbook of self and identity, NewYork, Guilford Press, (pp.268-289).

Ungar, M. (2004). A constructionist discourse on resilience. Youth \& Society, 35, 341-365.

Ungar, M. (2010). Researching culturally diverse pathways to resilience: Challenges and solutions. In H. M. McCubbin, K. Ontai, L. Kehl, L. McCubbin, I. Strom, H. Hart, and J. Matsuoka (Eds.), Multiethnicity and multiethnic families (pp. 253-276). Honolulu, HI: Le'a Press. 
Ungar, M. (2011). The social ecology of resilience. Addressing contextual and cultural ambiguity of a nascent construct. American Journal of Orthopsychiatry, 81, 1-17.

Vogus, T.J., Sutcliffe, K.M. (2007). Organizational resilience: Towards a theory and research agenda. Retrieved July 22, 2015 fromhttp://ieeexplore.ieee.org/stamp/stamp.jsp?tp=andarnumber=4414160.

Vroom, V.H. (1964). Work and Motivation. Wiley, New York.

Wagnild, G. M., Young, H. M. (1993). Development and psychometric evaluation of the Resilience Scale. Journal of Nursing Measurement, 1(2), 165-178.

Walker, B., Holling, C. S., Carpenter, S. R. and Kinzig. A. (2004). Resilience, adaptability and transformability in social-ecological systems. Ecology and Society, 9(2):5[online] URL: http://www.ecologyandsociety.org/vol9/iss2/art5/

Wang, C. and Ahmed, P. (2007). Dynamic capabilities: A review and research agenda. International Journal of Management Reviews, 9(1), 31-51.

Wei, Y. S., and Wang, Q. (2011). Making sense of a market information system for superior performance: The roles of organizational responsiveness and innovation strategy. Industrial Marketing Management, 40(2), 267277.

Weick, K. E. (1993). The collapse of sensemaking in organizations: The Mann Gulch disaster. Administrative Science Quarterly, 38, 628-652.

Youssef, C. M. and Luthans, F. (2007). Positive organizational behaviour in the workplace: The impact of hope, optimism, and resilience. Journal of Management, 33(5), 774-800.

Zamani, Z. A., Nasir, R., Desa, A., Khairudin, R., and Yusooff, F. (2014). Family Functioning, Cognitive Distortion and Resilience among Clients under Treatment in Drug Rehabilitation Centres in Malaysia. ProcediaSocial and Behavioral Sciences, 140, 150-154.

Zámečník, R. (2014). The measurement of employee motivation by using multi-factor statistical analysis. Procedia-Social and Behavioral Sciences, 109, 851-857.

Zeng, J., Phan, C. A., and Matsui, Y. (2015). The impact of hard and soft quality management on quality and innovation performance: An empirical study. International Journal of Production Economics, 162, 216-226. 